\title{
Anticarcinogenic properties of malic acid on glioblastoma cell line through necrotic cell death mechanism
}

\author{
Mehmet Enes Arslan \\ Department of Molecular Biology and Genetics, Faculty of Science, Erzurum Technical University, Erzurum, Turkey,
} enes.aslan@erzurum.edu.tr, ORCID: 0000-0002-1600-2305

\section{A B S T R A C T}

This study aimed to investigate the anticarcinogenic and genotoxic damage potentials of malic acid on human fibroblast cells (HDFa) and glioblastoma (U87-MG) cell lines. MTT cell viability and $\mathrm{LDH}$ release assays were performed to understand cytotoxic features of malic acid on different cell lines. Also, Hoechst 33258 fluorescent staining was used to monitor nuclear abnormalities including micronucleus, lobbed, and notched structures. Furthermore, cellular death mechanisms behind the malic acid application were investigated via the use of flow cytometry analysis. According to cell viability analysis, malic acid showed a greater effect on U87-MG compared to HDFa cell line in terms of cytotoxicity. Similarly, chromosomal integrity assay put forth a higher number of nuclear abnormalities in U87-MG cells when compared to HDFa cell lines, and aberrations were analyzed to amplify when malic acid concentration increased. Finally, flow cytometry analysis demonstrated higher necrotic cell death in U87-MG cells than HDFa cell line. On the other hand, apoptotic cell death was the main cytotoxic mechanism against malic acid exposure in the HDFa cell line. In light of these results, it can be concluded that in higher concentrations, malic acid has an anticarcinogenic effect on glioblastoma cells via the necrotic pathway, and it also shows apoptotic properties on the fibroblast cell line. When mutagenic properties are compared, it could be understood that malic acid had a greater impact on glioblastoma cells.

\section{Introduction}

Cancer is a destructive disease characterized by abnormalities in uncontrolled and rapidly dividing cells that cause the death of thousands of people worldwide every year. This is of great concern to people, as one in four people has a high risk of cancer. In the World Cancer Report, it was reported that cancer statistics could increase by $50 \%$ until 2020 and that 15 million people will be examined for several types of cancer [1-3]. Although glioblastoma is one of the most aggressive brain tumors, there are multiple treatment methods available such as surgery, radiation, and cytotoxic chemotherapy. On the other hand, recent clinic researches have shown an average survival of only 14-16 months with a 26-33\% 2-year survival rate $[4,5]$.

A number of natural compounds particularly abundant in plants have recently attracted much interest for their many biological properties including antioxidant, antitumor, antibacterial, antimutagen, and several others [6-9]. Malic acid, a type of alpha-hydroxy acid, is an organic acid that is used in many areas from food to cosmetics. It is a known fact that more than fifty cosmetic products contain malic acid $[10,11]$. Recent studies have shown that keratin-malate supplementation can be used as a performance-enhancing agent and increases the physical performance of athletes [12]. It has been investigated that a diet high in malic acid, which is the precursor of citrate, increases kidney stone formation [13]. The malic acid spray has been used orally to treat mouth dryness. The analysis showed that the symptoms were found to be improved in people with mouth dryness after two weeks of malic acid usage[14]. In addition to this, its availability as carrier systems for the release of poly (malic acid) targeted drugs has also been reported in many studies $[15,16]$. However, conditions such as redness, swelling, burning, phototoxicity caused by alpha hydroxy acids lead to safety concerns $[17,18]$.

Previous studies showed that tumor-specific targeting is important for increasing the effectiveness of anti-tumor drugs. According to the analysis, two different covalently conjugated antibodies to the poly ( $\beta$-L-malic acid) nanocarrier increased 
tumor targeting efficiency [19]. Simultaneous delivery to two different AON tumor cells was shown using Polycefin, a new nanoscale PMLA-based drug, that simultaneously blocks the in vivo expression of two laminin-8 chains. In another study, simultaneous delivery to two different AON tumor cells was shown using Polycefin, a new nanoscale PMLA-based drug, that simultaneously blocks the in vivo expression of two laminin-8 chains. It has been shown to inhibit laminin-8 synthesis in U87MG and T98G in cultured human glioma cells [20]. It was also stated that the immunoconjugates of poly L-malic acid prepared with CTLA-4 and PD-1 can get past the blood-brain barrier and trigger local immune responses for glioma cancer treatment [21].

In this study, MTT and LDH tests were performed to examine the effects of malic acid on cell viability on the U87-MG glioblastoma cell line. Hoechst 33258 staining was used to investigate the nuclear status of the cell cultures. Furthermore, flow cytometry analysis was performed to understand the underlying mechanisms behind the main cellular deaths. Meanwhile, the cytotoxicity and mutagenicity effects of the malic acid, one of the alpha-hydroxy acids, were analyzed on the HDFa human fibroblast cell line to create a safety report.

\section{Materials and methods}

\subsection{Cell cultures}

Human dermal fibroblast (HDFa) and glioblastoma (U87MG) cell cultures were supplied from American Type Culture Collection (ATCC). Solid L-malic acid (MA, CAS 97-67-6, Sigma Aldrich) was commercially available. The human fibroblast cells and glioblastoma cells were seeded in 48 well plates containing DMEM (\%10 FBS and $100 \mathrm{U} / \mathrm{ml}$ penicillinstreptomycin) about $10^{5}$ cells per well. Culture plates incubated at humidified $5 \% \mathrm{CO}_{2}$ at $37^{\circ} \mathrm{C}$ for 24 hours [22].

\subsection{MTT analysis}

MTT (3-(4,5-Dimethylthiazol-2-yl)- 2,5-diphenyltetrazolium bromide) assay, one of the most widely used viability tests, is a colorimetric analysis that measures metabolic activity using the reduction of a yellow tetrazolium salt. Culture plates were treated with L-malic acid at different concentrations (3.12 $\mu \mathrm{g} / \mathrm{mL}, 6.25 \mu \mathrm{g} / \mathrm{mL}, 12.5 \mu \mathrm{g} / \mathrm{mL}, 50 \mu \mathrm{g} / \mathrm{mL}, 100 \mu \mathrm{g} / \mathrm{mL}, 200$ $\mu \mathrm{g} / \mathrm{mL}, 400 \mu \mathrm{g} / \mathrm{mL})$. In addition, while the cells in the positive control group were treated with $1 \%$ Triton $\mathrm{X}-100$, no treatment was applied to the wells designated as negative control groups. After 24 hours of incubation, an MTT reagent was added to each well. Plates were incubated for 3 hours at humidified $5 \% \mathrm{CO}_{2}$ incubator at $37^{\circ} \mathrm{C}$ and culture medium was discarded. Generated formazan crystals were dissolved by using dimethyl sulfoxide. The plates were analyzed at $570 \mathrm{~nm}$ wavelength using a microplate reader [23].

\section{3. $\mathrm{LDH}$ release test}

LDH cytotoxicity assay kit (Cayman Chemical Company ${ }^{\circledR}$, Ann Arbor, MI, USA) was applied as per the manufacturer's instructions for the LDH assay application. The cells were seeded to 48 -well plates and wide spectrum concentrations of malic acid $(3.12 \mu \mathrm{g} / \mathrm{mL}, 6.25 \mu \mathrm{g} / \mathrm{mL}, 12.5 \mu \mathrm{g} / \mathrm{mL}, 50 \mu \mathrm{g} / \mathrm{mL}$, $100 \mu \mathrm{g} / \mathrm{mL}, 200 \mu \mathrm{g} / \mathrm{mL}, 400 \mu \mathrm{g} / \mathrm{mL}$ ) were administered to cell culture as triplicates for 24 hours at humidified $5 \% \mathrm{CO} 2$ incubator at $37^{\circ} \mathrm{C}$.. In addition, while the cells in the positive control group were treated with $1 \%$ Triton $\mathrm{X}-100$, no treatment was applied to the wells designated as negative control groups. After that, $100 \mu \mathrm{L}$ supernatant was transferred to a fresh 48 -well plate and $100 \mu \mathrm{L}$ of the reaction mixture was added to the samples and incubated for 30 minutes at room temperature. Finally, a microplate reader was used to analyze the absorbance of the cultures at $490 \mathrm{~nm}$ [24].

\subsection{Hoechst staining}

For the Hoechst Staining, firstly the medium was removed from the prepared culture plates by treating with different concentrations of L-malic acid. The wells were washed with PBS twice. Then cells were fixed $4 \%$ paraformaldehyde at $4{ }^{\circ} \mathrm{C}$ for 30 minutes. Cells were washed with PBS. Finally, wells were incubated with $1 \mathrm{mM}$ Hoechst 33258 fluorescent dye at room temperature for 5 minutes. Nuclear anomalies were calculated under a fluorescence microscope. A total of 1000 cells were counted and mutations were determined for both glioblastoma and fibroblast cell lines [25].

\subsection{Flow cytometry analysis}

Flow cytometry analysis was performed to examine the effectiveness of apoptosis, one of the cell death pathways. Annexin V was used to analyze apoptotic cells. Briefly, the phosphatidylserine structures, normally found in the inner surface of the cell membrane, rose to the surface of the cell membrane as the indicator of apoptotic cell death. To investigate the necrotic cell ratios, propidium iodide staining was used to analyze the cell nucleus. For this purpose, $5 \times 10^{4}$ cells were collected through centrifugation and the cells were resuspended in $500 \mu \mathrm{l}$ of $1 \mathrm{X}$ binding buffer. $5 \mu \mathrm{l}$ of Annexin $\mathrm{V}$-FITC and $5 \mu \mathrm{l}$ of propidium iodide $(50 \mu \mathrm{g} / \mathrm{ml})$ were added to the cultures and incubated in the dark for 5 minutes. The cells were then fixed with $4 \%$ paraformaldehyde in phosphatebuffered saline at $4{ }^{\circ} \mathrm{C}$ for 30 minutes. Finally, cultures were examined with flow cytometry (The CyFlow ${ }^{\circledR}$ Cube 6, Germany) [26].

\subsection{Statistical analysis}

Statistical analyzes of the numerical data collected from the studies were performed using GraphPad Prism 7. Anova: Dunnett's and Tukey multiple comparison tests were performed following the Two Way Anova analysis for statistical evaluation, and the statistical significance level was accepted as $\mathrm{p}<0.05$. 


\section{Findings}

Both MTT and LDH cytotoxicity assays showed that malic acid application for 24 hours significantly decreased cell viability in fibroblast cell culture at 100, 200, and $400 \mu \mathrm{g} / \mathrm{ml}$ concentrations, however, there was no significant cell viability difference compared to the negative control in lower concentrations (50 -3.12 $\mu \mathrm{g} / \mathrm{ml}$ ) (Figure 1). On the other hand, malic acid exposure inhibited cell growth in glioblastoma cell lines significantly, even at smaller concentration levels as 12,5 to $400 \mu \mathrm{g} / \mathrm{ml}$ compared to fibroblast cell lines (Figure 2).

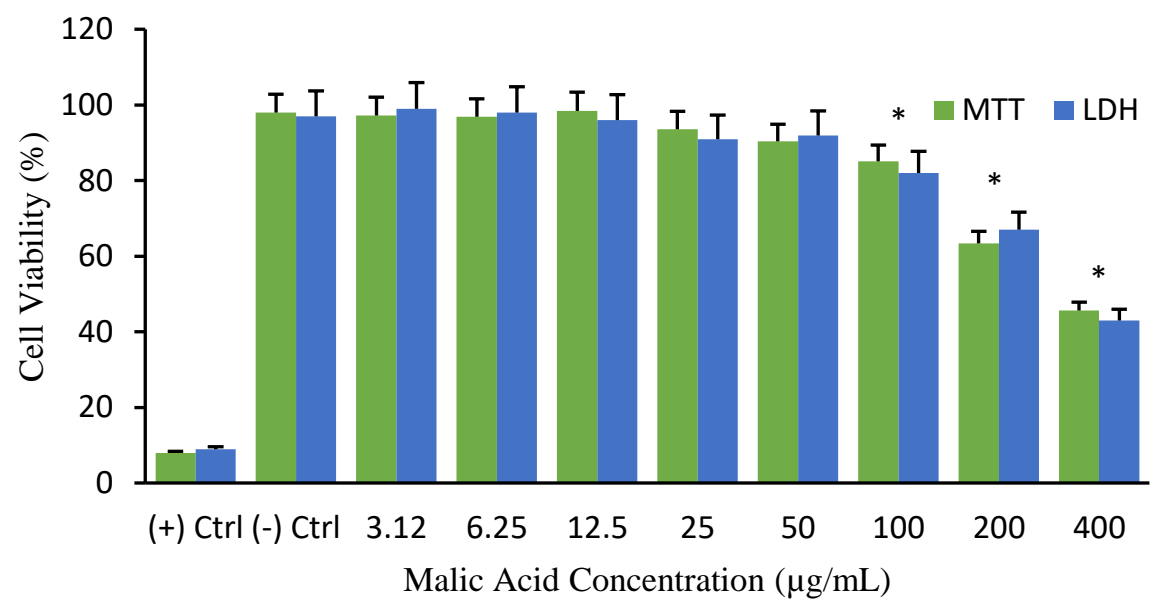

Figure 1: Cell viability tests (MTT and LDH assays) of the fibroblast cell line (HDFa) against the malic acid application (3,12 to 400 $\mu \mathrm{g} / \mathrm{ml})$ for 24 hours. Symbol $(*)$ represents a statistically significant difference $(P<0.05)$ compared to the negative control. (GraphPad Prism 7, Anova: Tukey's post hoc test was used to calculate significantly different values)

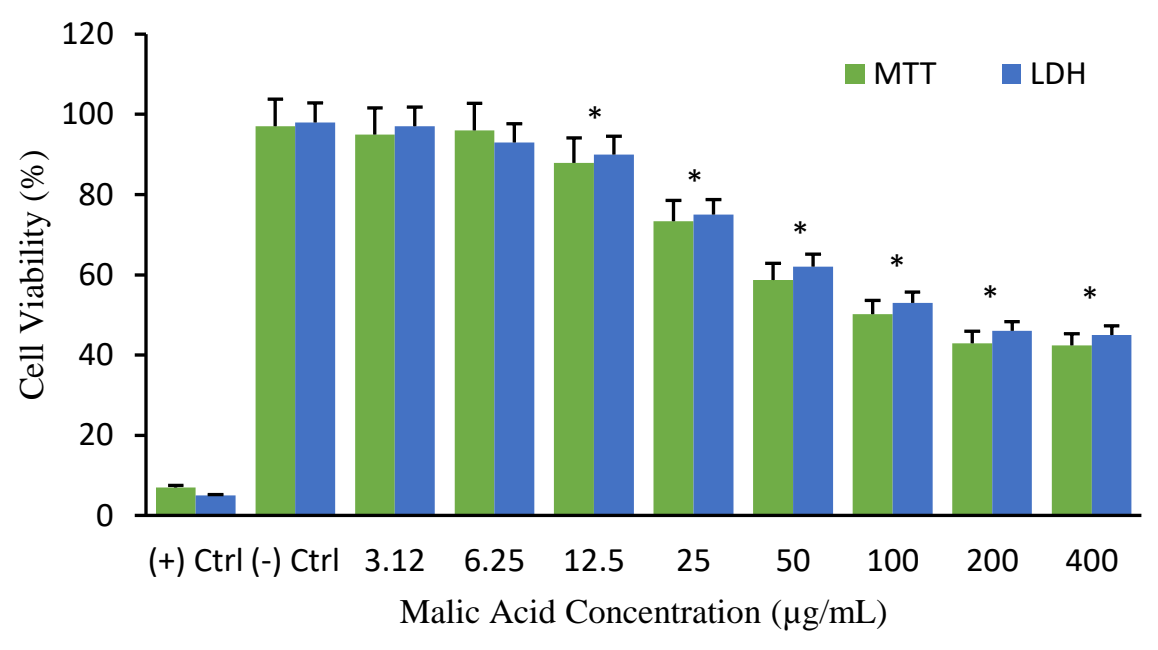

Figure 2: Cell viability tests (MTT and LDH assays) on glioblastoma cells (U87-MG) against the malic acid application (3,12 to 400 $\mu \mathrm{g} / \mathrm{ml}$ ) for 24 hours. Symbol $(*)$ represents a statistically significant difference $(P<0.05)$ compared to the negative control. (GraphPad Prism 7, Anova: Tukey's post hoc test was used to calculate significantly different values)

Secondly, Hoechst 33258 fluorescent staining analysis put forth that malic acid in higher concentrations affects nuclear structures negatively in both fibroblast and glioblastoma cell lines. Observable nucleus mutations such as micronucleus, 
lobbed and notch structures were highly increased in respect to malic acid exposure (Figure 3 and 4). When two cell lines were compared to each other in terms of nuclear mutations, it was found that malic acid had more severe effects on glioblastoma cell lines with a greater number of mutations specifically in higher concentrations in contrast to fibroblast cells (Table 1).

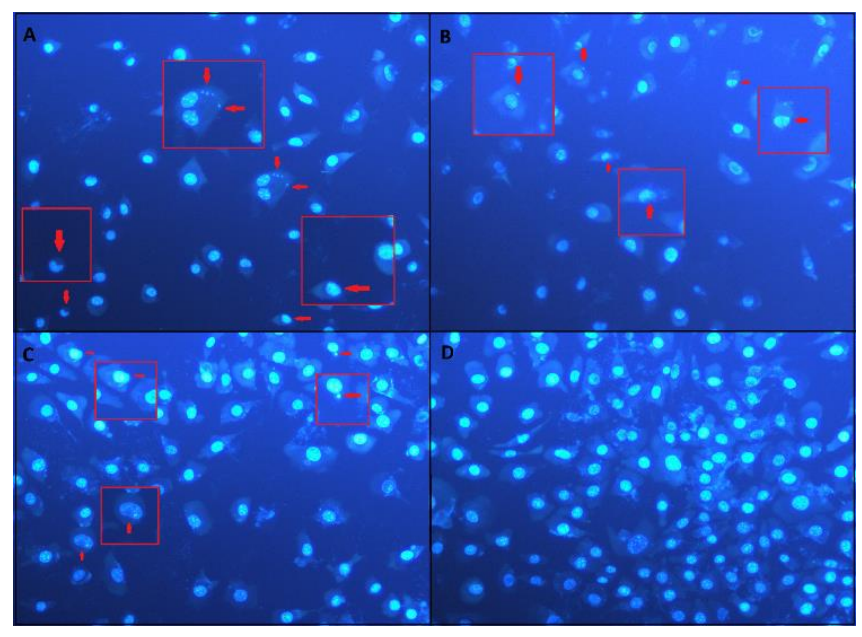

Figure 3: Hoechst 33258 fluorescent staining of Fibroblast cell line for nuclear abnormalities (20X magnifications). A) $400 \mu \mathrm{g} / \mathrm{ml}$ malic acid application for 24 hours, B) $200 \mu \mathrm{g} / \mathrm{ml}$ malic acid application for 24 hours, $C$ ) $100 \mu \mathrm{g} / \mathrm{ml}$ malic acid application for
24 hours, D) Negative control fibroblast cell line culture without malic acid application (arrows indicate nuclear abnormalities)

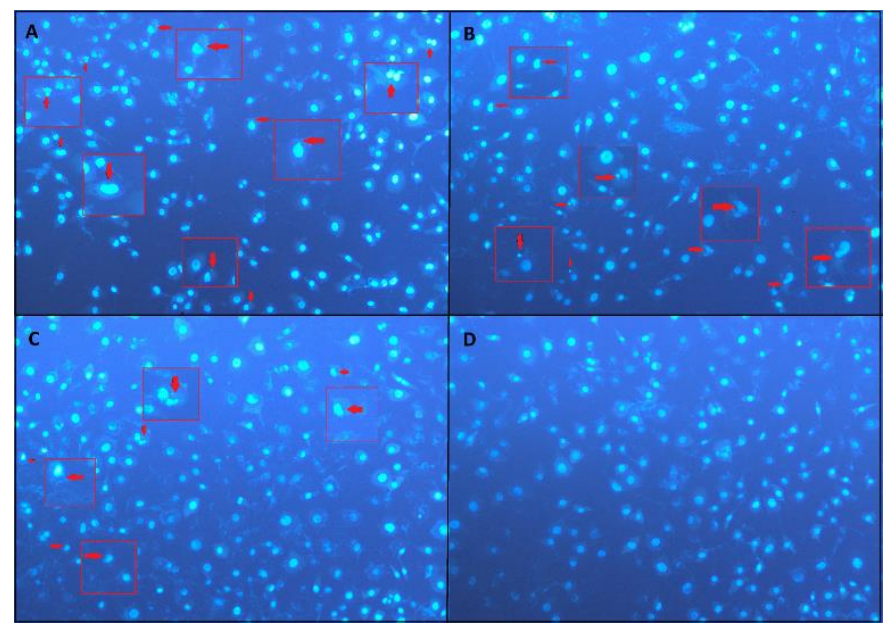

Figure 4: Hoechst 33258 fluorescent staining of glioblastoma cells (U87-MG) for nuclear abnormalities (20X magnifications). A) $400 \mu \mathrm{g} / \mathrm{ml}$ malic acid application for 24 hours, B) $200 \mu \mathrm{g} / \mathrm{ml}$ malic acid application for 24 hours, C) $100 \mu \mathrm{g} / \mathrm{ml}$ malic acid application for 24 hours, D) Negative control (U87-MG) cell culture without malic acid application (arrows indicate nuclear abnormalities)

Table 1: Nuclear abnormalities (NA) in Fibroblast (HDFa) and Glioblastoma (U87-MG) cell lines against malic acid applications in various concentrations. Values are mean \pm SEM (standard error of the mean) from 3 samples for every 1000 cells. Different letters in the same column represent statistical differences from each other. Calculations were performed after 24 hours of application. (GraphPad Prism 7, Anova: Dunnett's multiple comparison test was used to calculate the significantly different samples)

\begin{tabular}{|c|c|c|c|c|}
\hline \multirow{2}{*}{$\begin{array}{l}\text { Treatment } \\
\text { HDFa }\end{array}$} & \multicolumn{4}{|c|}{ Nuclear abnormalities (NA) } \\
\hline & Total MN & Total lobbed & Total notched & Mean NA/1000 cells \pm SD \\
\hline $400 \mu \mathrm{g} / \mathrm{ml}$ & 45 & 15 & 14 & $0,074 \pm 0,005^{\mathrm{a}}$ \\
\hline $200 \mu \mathrm{g} / \mathrm{ml}$ & 20 & 12 & 11 & $0,043 \pm 0,003^{\mathrm{b}}$ \\
\hline $100 \mu \mathrm{g} / \mathrm{ml}$ & 9 & 11 & 9 & $0,029 \pm 0,002^{\mathrm{c}}$ \\
\hline (-) $\mathrm{Ctrl}$ & 5 & 3 & 2 & $0,010 \pm 0,002^{\mathrm{d}}$ \\
\hline U87-MG & Total MN & Total lobbed & Total notched & Mean NA/1000 cells \pm SD \\
\hline $400 \mu \mathrm{g} / \mathrm{ml}$ & 54 & 20 & 19 & $0,093 \pm 0,007^{\mathrm{e}}$ \\
\hline $200 \mu \mathrm{g} / \mathrm{ml}$ & 29 & 16 & 17 & $0,062 \pm 0,005^{\mathrm{f}}$ \\
\hline $100 \mu \mathrm{g} / \mathrm{ml}$ & 15 & 8 & 10 & $0,033 \pm 0,003^{c}$ \\
\hline (-) $\mathrm{Ctrl}$ & 7 & 8 & 8 & $0,023 \pm 0,002^{\mathrm{g}}$ \\
\hline
\end{tabular}


To examine the cytotoxicity mechanism behind the malic acid applications, Flow Cytometry analysis was performed on both fibroblast and glioblastoma cell lines for different concentrations of malic acid exposures (100, 200, and 400 $\mu \mathrm{g} / \mathrm{ml})$. In these examinations, the viable cell ratio was found to be inversely proportional to malic acid concentrations. Flow Cytometry results showed that cell viabilities were analyzed as $42.24 \%, 56.25 \%$, and $72.39 \%$ for $400 \mu \mathrm{g} / \mathrm{ml}, 200$ $\mu \mathrm{g} / \mathrm{ml}$, and $100 \mu \mathrm{g} / \mathrm{ml}$ concentration of malic acid respectively (Figure 5). In addition, it was observed that fibroblast cells decrease predominantly by apoptotic cell death mechanism. Furthermore, Flow Cytometry examinations on glioblastoma cell lines produced very opposite results. Necrotic cell death was observed after 24 hours of malic acid application to the glioblastoma cell culture and live-cell ratios were found to be $46.68 \%, 56.82 \%$, and $70.73 \%$ for $400 \mu \mathrm{g} / \mathrm{ml}, 200 \mu \mathrm{g} / \mathrm{ml}$, and $100 \mu \mathrm{g} / \mathrm{ml}$ malic acid concentrations (Figure 6).
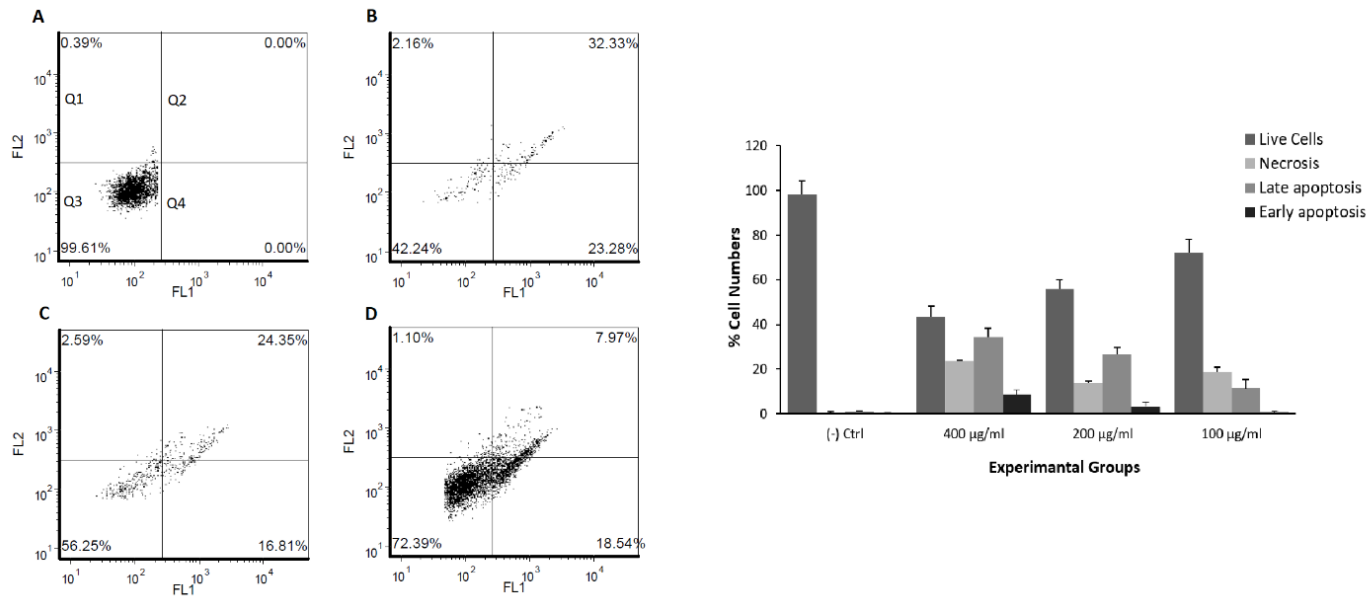

Figure 5: Flow Cytometry analysis (Annexin V- (FL1-H) and PI- (FL2-H) labeled cells) of Fibroblast cell line against malic acid cytotoxicity. A) Negative control for 24 hours, B) $400 \mu \mathrm{g} / \mathrm{ml}$ malic acid application for 24 hours, $\boldsymbol{C}) 200 \mu \mathrm{g} / \mathrm{ml}$ malic acid application for 24 hours, D) $100 \mu \mathrm{g} / \mathrm{ml}$ malic acid application for 24 hours. (Q1: Necrotic cells, Q2: Late apoptotic cells, Q3: living cells, and Q4: early apoptotic cells)
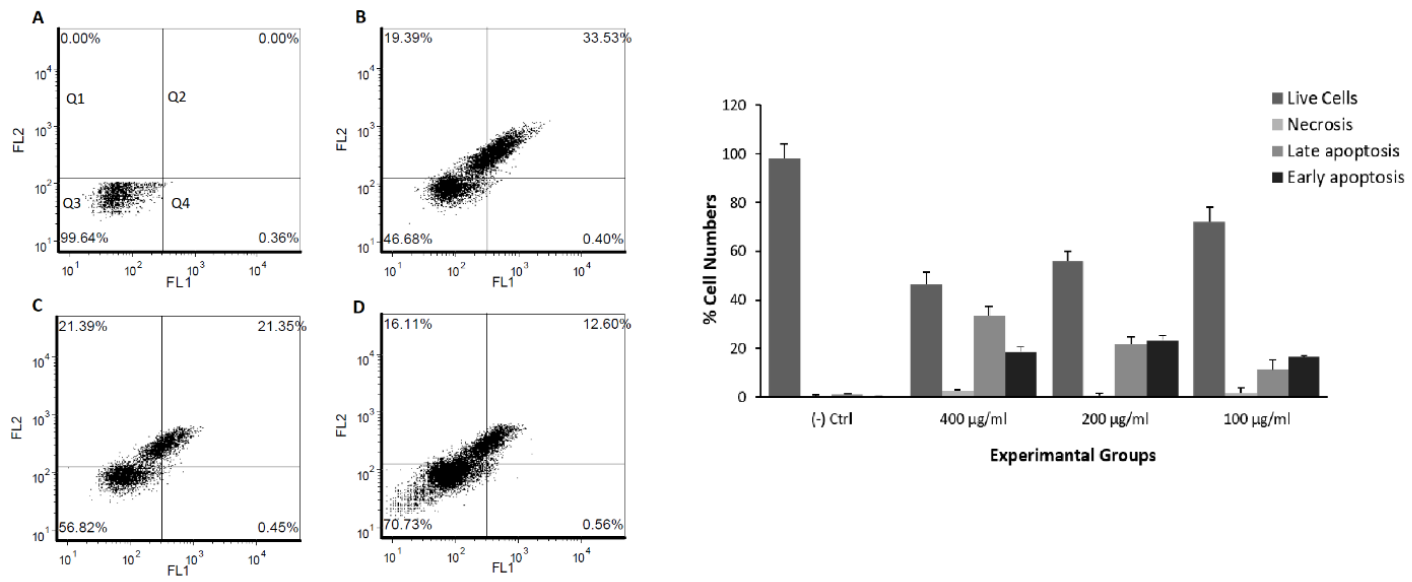

Figure 6: Flow Cytometry analysis (Annexin V- (FL1-H) and PI- (FL2-H) labeled cells) of U87-MG cells against malic acid cytotoxicity. A) Negative control for 24 hours, B) $400 \mu \mathrm{g} / \mathrm{ml}$ malic acid application for 24 hours, $\boldsymbol{C}) 200 \mu \mathrm{g} / \mathrm{ml}$ malic acid application for 24 hours, D) $100 \mu \mathrm{g} / \mathrm{ml}$ malic acid application for 24 hours. (Q1: Necrotic cells, Q2: Late apoptotic cells, Q3: living cells, and Q4: early apoptotic cells) 


\section{Discussions}

Malic acid is one of the most important chemicals used as a nutritional enhancer in the food industry. Malic acid's specific features such as hygroscopicity and increasing storage capability make it a commercially favorable molecule for several industries [27,28]. Besides, malic acid applications in the medical industry have a wide range of potential for skin problems such as warts and acne with its favorable features such as easiness to apply, being cheap, and having no serious adverse effects [29]. In our study, it was shown that lower concentrations of malic acid (50 to $3.12 \mu \mathrm{g} / \mathrm{ml}$ ) had no significant toxic effects on the fibroblast cell lines. This result could indicate that under specific concentrations, malic acid applications would not show any crucial side effects on human health. Contrarily, cell viability assays on glioblastoma cell lines expressed the anticarcinogenic activity of malic acid even for lower concentrations (up to $12.5 \mu \mathrm{g} / \mathrm{ml}$ ). It could be proposed that malic acid derivatives with enhanced activity could be used as anticancer agents for specific tumor treatments under certain doses without damaging healthy cells. Previous studies claimed that 5-fluorouracils conjugated poly ( $\alpha$-malic acid) caused no toxicity however, the molecule showed increased antitumor property on P-388 lymphocytic leukemia mice models [30]. Moreover, different conjugates of malic acid such as poly ( $\alpha$-malic acid)/ADR(Adriamycin) were analyzed to examine anticarcinogenic activity on human hepatoma cells in vitro [31]. In a study, Poly ( $\beta$-malic acid) (PMLA) conjugated chitosan (LMC) nanoparticles were used as a co-delivery of the antitumor drug system for paclitaxel (PTX) delivery. Applications of the conjugates on hepatomabearing mice models were analyzed to examine prolonged survival periods and enhanced antitumor efficacy.

In this study, Hoechst 33258 fluorescent staining was used to analyze the genotoxic potential of malic acid on both fibroblast and glioblastoma cell lines. Malic acid was shown to have higher genotoxic activity against glioblastoma cell lines. Although genotoxic activity was shown on the glioblastoma cell line rather than fibroblast cells at higher concentrations in our study, several projects claimed the nongenotoxic potential of malic acid [32-34]. Besides, it was revealed previously that malic acid had genotoxic potential when reacted with trichloroacetaldehyde in an aqueous solution [11]. Ameliorating effects of malic acid against heavy metals such as cadmium $(\mathrm{Cd})$ were examined in a previous research study. This study revealed that malic acid could reduce mutagenic ROS production resulted from $\mathrm{Cd}$ accumulation by enhancing cellular glutathione level [35]. Furthermore, several studies examined the protective effect of malic acid against aluminum-induced toxicity in vitro and in vivo [36-38].

In addition to these examinations, Flow Cytometry analysis indicated interesting results related to cellular death mechanisms in healthy and cancer cell lines against malic acid applications. Flow Cytometry analysis on fibroblast cells revealed that malic acid exposure to the healthy cell type resulted in apoptotic cell death. This finding correlated with the literature that malic acid application to the immortalized human keratinocyte line $(\mathrm{HaCaT})$ was shown to activate mitochondria-dependent and endoplasmic reticulum stressrelated apoptosis [18]. On the other hand, this study examined for the first time that low concentration of malic acid application to the glioblastoma cell line induced necrotic cell death. Flow Cytometry analysis showed that the increased concentrations of malic acid lead glioblastoma cells to late apoptotic death rather than necrosis.

\section{Conclusion}

In light of these findings, it can be understood that malic acid has anticarcinogenic activity against glioblastoma cell lines even at lower concentrations. According to genotoxicity and cytotoxicity analysis on the fibroblast cell lines, higher concentrations of malic acid can result in a mutagenic outcome however, under certain concentrations, no adverse reactions are observed. Interestingly, the cytotoxicity mechanism of malic acid on fibroblast cell lines is apoptosis at high concentrations. On the other hand, glioblastoma cells have a more necrotic tendency towards malic acid applications. From these examinations, it is concluded that malic acid applications at specific concentrations can be used as an anticancer agent without causing any detrimental and mutagenic properties.

\section{References}

[1] Pal SK, Mittal B. "Improving cancer care in India: Prospects and challenges", Asian Pacific J Cancer Prev 5, (2004), 226-228.

[2] Caparica R, Júlio A, Araújo MEM, Baby AR, Fonte P, Costa JG, et al. "Anticancer Activity of Rutin and Its Combination with Ionic Liquids on Renal Cells", Biomolecules, 10, (2020), 233.

[3] Pitucha M, Korga-Plewko A, Kozyra P, Iwan M, Kaczor AA. "2,4-Dichlorophenoxyacetic Thiosemicarbazides as a New Class of Compounds against Stomach Cancer Potentially Intercalating with DNA", Biomolecules, 10, (2020), 296.

[4] Lambert J-C, Ibrahim-Verbaas CA, Harold D, Naj AC, Sims R, Bellenguez C, et al. "Meta-analysis of 74,046 individuals identifies 11 new susceptibility loci for Alzheimer's disease", Nat Genet, 45, (2013), 14521458.

[5] Sato A, Sunayama J, Okada M, Watanabe E, Seino S, Shibuya K, et al. "Glioma-Initiating Cell Elimination by Metformin Activation of FOXO3 via AMPK. Stem Cells", Transl Med, 1, (2012), 811-824 
[6] Marinelli L, Fornasari E, Eusepi P, Ciulla M, Genovese $\mathrm{S}$, Epifano $\mathrm{F}$, et al. "Carvacrol prodrugs as novel antimicrobial agents", Eur J Med Chem, 178, (2019), 515-529.

[7] Turkez H, Togar B, Polat E. "Olive leaf extract modulates permethrin induced genetic and oxidative damage in rats", Cytotechnology, 64, (2012), 459-464.

[8] Turkez H, Geyikoglu F, Yousef MI. "Beneficial effect of astaxanthin on 2,3,7,8-tetrachlorodibenzo- $\mathrm{p}$-dioxininduced liver injury in rats", Toxicol Ind Health, 29, (2013), 591-599.

[9] Ploskonos M v., Syatkin S p., Neborak E v., Hilal A, Sungrapova K y., Sokuyev R i., et al. "Polyamine Analogues of Propanediamine Series Inhibit Prostate Tumor Cell Growth and Activate the Polyamine Catabolic Pathway", Anticancer Res, 40, (2020), 14371441.

[10] Al Bawab A, Friberg SE, Bergamaschi MM, Santos ODH. "Some non-equilibrium phenomena in the malic acid/water/Polysorbate 81 system", Int J Pharm, 332, (2007), 140-146.

[11] Fiume MZ. "Final Report on the Safety Assessment of Malic Acid and Sodium Malate", Int J Toxicol, 20, (2001), 47-55.

[12] Tyka AK, Chwastowski M, Cison T, Palka T, Tyka A, Szygula Z, et al. "Effect of creatine malate supplementation on physical performance, body composition and selected hormone levels in spinters and long-distance runners", Acta Physiol Hung, 102, (2015), 114-122.

[13] Manfredini R, De Giorgi A, Storari A, Fabbian F. "Pears and renal stones: Possible weapon for prevention? A comprehensive narrative review", Eur Rev Med Pharmacol Sci, 20, (2016), 414-25

[14] Gõmez-Moreno G, Aguilar-Salvatierra A, Guardia J, Uribe-Marioni A, Cabrera-Ayala M, Delgado-Ruiz RA, et al. "The efficacy of a topical sialogogue spray containing $1 \%$ malic acid in patients with antidepressant-induced dry mouth: A double-blind, randomized clinical trial", Depress Anxiety, 30, (2013), 137-142.

[15] Ljubimova JY, Fujita M, Khazenzon NM, Lee B-S, Wachsmann-Hogiu S, Farkas DL, et al. "Nanoconjugate based on polymalic acid for tumor targeting", Chem Biol Interact, 171, (2008), 195-203.

[16] Ljubimova JY, Fujita M, Ljubimov A V., Torchilin VP, Black KL, Holler E. "Poly(malic acid) nanoconjugates containing various antibodies and oligonucleotides for multitargeting drug delivery", Nanomedicine, 3, (2008), 247-265.

[17] Tang S-C, Yang J-H. Dual "Effects of Alpha-Hydroxy
Acids on the Skin", Molecules, 23, (2018), 863.

[18] Hsiao Y-P, Lai W-W, Wu S-B, Tsai C-H, Tang S-C, Chung J-G, et al. "Triggering Apoptotic Death of Human Epidermal Keratinocytes by Malic Acid: Involvement of Endoplasmic Reticulum Stress- and Mitochondria-Dependent Signaling Pathways", Toxins (Basel), 7, (2015), 81-96.

[19] Fujita M, Lee B-S, Khazenzon NM, Penichet ML, Wawrowsky KA, Patil R, et al. "Brain tumor tandem targeting using a combination of monoclonal antibodies attached to biopoly( $\beta-1-$ malic acid)", J Control Release, 122, (2007), 356-363.

[20] Fujita M, Khazenzon NM, Ljubimov A V., Lee B-S, Virtanen I, Holler E, et al. "Inhibition of laminin-8 in vivo using a novel poly(malic acid)-based carrier reduces glioma angiogenesis", Angiogenesis, 9, (2006), 183-191

[21] Galstyan A, Markman JL, Shatalova ES, Chiechi A, Korman AJ, Patil R, et al. "Blood-brain barrier permeable nano immunoconjugates induce local immune responses for glioma therapy", Nat Commun, 10, (2019), 3850.

[22] Emsen B, Aslan A, Turkez H, Joughi A, Kaya A. "The anti-cancer efficacies of diffractaic, lobaric, and usnic acid: In vitro inhibition of glioma", J Cancer Res Ther, 14, (2018), 941.

[23] Türkez H, Arslan ME, Özdemir Ö, Chikha O. "Ameliorative effect of boric acid against nicotineinduced cytotoxicity on cultured human primary alveolar epithelial cells", BORON, 1, (2016), 104-109.

[24] Türkez H, Arslan ME, Sönmez E, Açikyildiz M, Tatar A, Geyikoğlu F. "Synthesis, characterization and cytotoxicity of boron nitride nanoparticles: emphasis on toxicogenomics", Cytotechnology, 71, (2019), 351-361.

[25] Turkez H, Arslan ME, Ozdemir O. "Genotoxicity testing: progress and prospects for the next decade", Expert Opin Drug Metab Toxicol, 13, (2017), 1-10.

[26] Marinelli L, Fornasari E, Di Stefano A, Turkez H, Arslan ME, Eusepi P, et al. "(R)- $\alpha$-Lipoyl-Gly-L-Pro-LGlu dimethyl ester as dual acting agent for the treatment of Alzheimer's disease", Neuropeptides, 66, (2017), 5258.

[27] Iyyappan J, Bharathiraja B, Baskar G, Kamalanaban E. "Process optimization and kinetic analysis of malic acid production from crude glycerol using Aspergillus niger", Bioresour Technol, 281, (2019), 18-25.

[28] Dai Z, Zhou H, Zhang S, Gu H, Yang Q, Zhang W, et al. "Current advance in biological production of malic acid using wild type and metabolic engineered strains", Bioresour Technol, 258, (2018), 345-353.

[29] Chiriac A, Brzezinski P. "Topical malic acid in 
combination with citric acid: an option to treat recalcitrant warts", Dermatol Ther, 28, (2015), 336-338.

[30] Ouchi T, Fujino A, Tanaka K, Banba T. "Synthesis and antitumor activity of conjugates of poly( $\alpha$-malic acid) and 5-fluorouracils bound via ester, amide or carbamoyl bonds", J Control Release, 12, (1990), 143-153.

[31] Ouchi T, Kobayashi H, Hirai K, Ohya Y. "Design of Poly $(\alpha$-malic acid)_Antitumor Drug-Saccharide Conjugate Exhibiting Cell-Specific Antitumor Activity", Pol Del Sys, 520, (1993), 382-94.

[32] Al-Ani FY, Al-Lami SK. "Absence of mutagenic activity of acidity regulators in the Ames Salmonella/microsome test", Mutat Res Toxicol, 206, (1988), 467-470.

[33] Kuroda M, Yoshida D, Mizusaki S. "Mutagenicity of pyrolyzates of natural substances toward Salmonella typhimurium TA97", Agric Biol Chem, 49, (1985), 1893-1895.

[34] Ishidate M, Sofuni T, Yoshikawa K, Hayashi M, Nohmi T, Sawada M, et al. "Primary mutagenicity screening of food additives currently used in Japan", Food Chem
Toxicol, 22, (1984), 623-636.

[35] Guo H, Chen H, Hong C, Jiang D, Zheng B. "Exogenous malic acid alleviates cadmium toxicity in Miscanthus sacchariflorus through enhancing photosynthetic capacity and restraining ROS accumulation", Ecotoxicol Environ Saf, 141, (2017), 119-128.

[36] Domingo JL, Gómez M, Llobet JM, Corbella J. "Citric, malic and succinic acids as possible alternatives to deferoxamine in aluminum toxicity", J Toxicol Clin Toxicol, 26, (1988), 67-79.

[37] Majida A.J. al-Qayim and Sawsan Mashi. "Renal effects of propolis and malic acid in Aluminium Exposed Male Rats", Appl Sci Reports, 1, (2014).

[38] Al-qayim MAJ, Saadoon D. "Assessment of the Ameliorative Role of Proplis and Malic Acid in Intestinal and Liver Functions of Aluminum", Int J Sci Nat, (2013). 